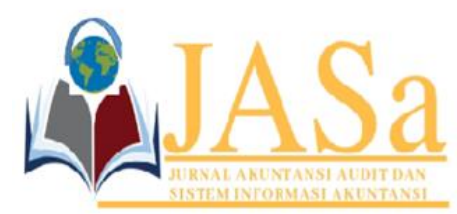

JASa (Jurnal Akuntansi, Audit dan Sistem Informasi Akuntansi)

Vol. 5 No.1/ April 2021

ISSN 2550-0732 print / ISSN 2655-8319 online

DOI;10.36555/jasa.v5i1.1507

\title{
THE INFLUENCE OF INTERNAL CONTROL SYSTEMS AND ACCOUNTING INFORMATION SYSTEMS ON GOOD CORPORATE GOVERNANCE
}

\author{
Kamilia Lestari \\ Universitas Padjadjaran, Indonesia \\ kamilia19001@mail.unpad.co.id
}

\begin{abstract}
This study aims to determine how the influence of internal control systems and accounting information systems on good corporate governance at Perum Bulog (Logistics Business Entity) in Bandung City. The factors tested in this study are the internal control system and the accounting information system as independent variables. Meanwhile, good corporate governance is the dependent variable. The research method used in this research is the verification method. The study population was employees of Perum Bulog (Logistics Business Entity Public Company) in Bandung, totaling 4,151 employees. The sampling technique used was probability sampling with a simple random sampling method using the Slovin formula, so that there were 97 employees of Perum Bulog in Bandung City. The analytical method used is multiple linear regression analysis using SPSS Version 23.00. The results of the research partially and simultaneously show that the internal control system and accounting information system have an effect on good corporate governance at Bulog Corporation in Bandung City. Also, the magnitude of the influence of the internal control system and accounting information system in contributing to good corporate governance is $77.2 \%$.
\end{abstract}

Keywords: Accounting Information Systems, Good Corporate Governance, Internal Control Systems.

\section{INTRODUCTION}

Currently, almost all companies, both private, state-owned, and regional, have implemented good corporate governance in achieving company goals. Good governance is a function of governing, one of which contains the principle of providing good community service by government officials in all aspects of life. According to the State Administration Institute, good governance is the implementation of a solid and responsible state government, as well as efficiency and effectiveness by maintaining the synergy of constructive interactions between the domains of the state, private sector, and society (Kurniawan, 2005, p. 16).

One of the companies that are obliged to implement good corporate governance is a company that is included in the state-owned company (BUMN). This is by with the Regulation of the Minister for State-Owned Enterprises Number: PER01/MBU/2011 concerning the Implementation of Good Corporate Governance in StateOwned Enterprises. According to the Regulation of the Minister for State-Owned Enterprises Number: PER-01/MBU/2011 states that State-Owned Enterprises, hereinafter referred to as BUMN, are business entities whose entire or most of the 


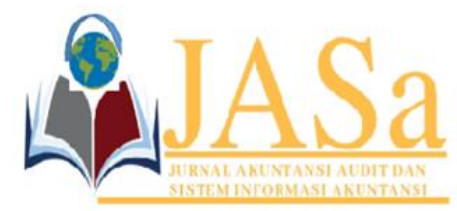

JASa (Jurnal Akuntansi, Audit dan Sistem Informasi Akuntansi)

Vol. 5 No.1/ April 2021

ISSN 2550-0732 print / ISSN 2655-8319 online

DOI; $10.36555 /$ jasa.v5i1.1507

capital is owned by the State through direct participation originating from separated state assets (Peraturan Menteri Badan Usaha Milik Negara, 2011).

In general, the aim of implementing good corporate governance in State-Owned Enterprises (BUMN) is to optimize the value of BUMN so that the company has strong competitiveness, both nationally and internationally, so that it can maintain its existence and live sustainably to achieve the goals and objectives of BUMN. Good corporate governance is a set of rules governing the relationship between company holders, management (managers), creditors, government, employees, and other internal and external stakeholders relating to their rights and obligations or in other words a system that controls companies (Sedarmayanti, 2012, p. 52). The purpose of corporate governance is to create added value for all interested parties (Sedarmayanti, 2012, p. 52).

However, there are still various cases that show the weak implementation of good corporate governance in State-Owned Enterprises (BUMN) which causes state losses. One of them is Perum Bulog. Several cases that occur in state-owned companies (BUMN) show that the implementation of good corporate governance is still weak. Weak implementation of good corporate governance is seen from the number of cases that occur in state-owned companies (BUMN) which result in state losses. One of the state-owned companies (BUMN) that still shows weaknesses in the implementation of good corporate governance is Perum Bulog. Apart from that, the cases above show that the weaknesses in the implementation of good corporate governance emphasize the principles of good corporate governance, accountability, and accountability.

One of the efforts to create a government capable of implementing good governance practices is by increasing the effectiveness of the internal control system and the accounting information system. The internal control system is a process that is influenced by the board of directors, management, and employees which is designed to provide convincing assurance that organizational goals will be achieved through efficiency and effectiveness of operations, the presentation of reliable financial reports, and compliance with laws and regulations. applicable regulations (Susanto, 2013, p. 95). Information systems are also very important in supporting good corporate governance. The accounting information system is a system used to collect, record, store, and process data to produce information for decision making (Romney dan Steinbart, 2015, p. 10). In the principle of accountability, managers are obliged to develop an effective accounting information system to produce reliable financial statements (Agoes dan Ardana, 2013, p. 103).

Several previous studies related to this research, namely research conducted by Widjaja dan Mustamu (2014), the results of their research show that the internal control system affects the implementation of the principles of good corporate governance. Also, research conducted by Windasari (2015) shows that internal audit and accounting information systems affect good corporate governance.

An internal control system is a process that is designed, implemented, and maintained by those responsible for governance, management, and other personnel to provide adequate assurance about the achievement of an entity's objectives relating to 


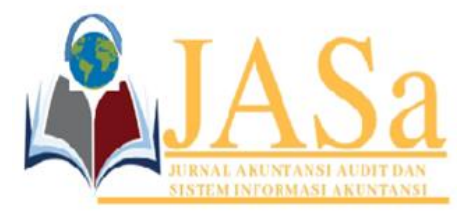

JASa (Jurnal Akuntansi, Audit dan Sistem Informasi Akuntansi)

Vol. 5 No.1/ April 2021

ISSN 2550-0732 print / ISSN 2655-8319 online

DOI;10.36555/jasa.v5i1.1507

the reliability of financial statements, operating efficiency, effectiveness, and compliance with legislation (Agoes, 2017, p. 162). According to the Committee of Sponsoring Organization of the Treadway Commission (COSO) in Redding et al., (2013, p. 9), there are five components of internal control, namely

Control Environment Consists of actions, policies, and procedures that reflect the attitude of top management, directors, and owners of the entity as a whole regarding internal control and its importance to the entity.

Risk Assessment, All companies will face risks that can threaten the achievement of company goals. All risks, both internal risks and external risks, must be assessed. COSO states that every company faces a variety of risks that come from within and from outside. Risk is defined as the likelihood that an event will arise and affect the achievement of goals.

Control activities are policies and procedures that help ensure that the necessary actions are taken to deal with risks to achieve company objectives. Control activities consist of actions taken by management, boards, and other parties to reduce risk and increase the likelihood that goals and objectives will be achieved. Therefore, control activities are carried out at all levels of the organization.

High-quality information must be communicated appropriately. Relevant, accurate, and timely information must be made available to individuals at all levels in an organization who need the information to conduct their business effectively. The information must be made available to specific parties to support operational achievement, reporting, and compliance. Also, communication must take place broadly in terms of achievements, responsibilities of each individual or group, and other important matters.

Monitoring activities relate to the continuous or periodic assessment of the quality of internal controls by management to determine that the controls are operating as expected, and have been modified according to changing conditions. The information assessed comes from a variety of sources, including studies of existing internal controls, internal auditor reports, and feedback from operational personnel. Monitoring activities will be more effective when a multilevel approach is implemented. The first level includes the daily activities carried out by management. The second level is a separate evaluation of internal control carried out by management to ensure that deficiencies are identified and resolved promptly. The third level is independent assessment, for example, the internal audit function to ensure the results (accuracy and reliability) of management's assessment of control effectiveness. Therefore, monitoring activities must be included in all components of internal control.

The accounting information system is a collection (integration) of sub-systems or components, both physical and non-physical, which are interconnected and harmoniously cooperate to process transaction data related to financial issues into financial information (Susanto, 2013, p. 72). According to Susanto (2013, p. 72) states that the components of the accounting information system are: Hardware is divided into several parts such as the input section, the processing or procedures and memory section, the output section, and the communications section. Software is divided into two major groups, namely system software, and application software. The system 


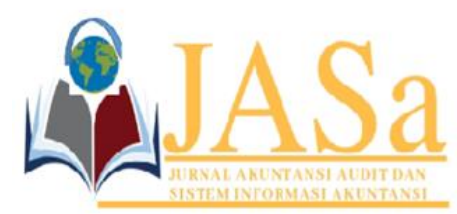

JASa (Jurnal Akuntansi, Audit dan Sistem Informasi Akuntansi)

Vol. 5 No.1/ April 2021

ISSN 2550-0732 print / ISSN 2655-8319 online

DOI; $10.36555 /$ jasa.v5i1.1507

software is divided into several groups, namely operating systems, interpreters, and compilers. While application software is divided into several types of software depending on the application used.

Humans are people who own, build and operate accounting information systems. The term people here is not haphazard people in the true sense of being but people who have the competence (knowledge and skills or expertise) according to their level in information systems. Procedures are guidelines that must be followed and form based on an agreement with the determination and approval of the authorized management. Database in a broad sense is data that is in the company, while in a narrow sense, the database is data that is on the computer.

Network Communications

A communication network or what is called a data network is the use of electronic media to move data from one location or several locations to another.

The Forum for Corporate Governance in Indonesia (FCGI) (2006) states that good corporate governance is a set of regulations governing the relationship between shareholders, company management, creditors, government, employees, and other internal and external stakeholders. with their rights and obligations or in other words, a system that controls the company (Agoes dan Ardana, 2013, p. 101). Regulation of the Minister for State-Owned Enterprises Number: PER-01/MBU/2011 in Agoes dan Ardana (2013, p. 103) states that the principles of corporate governance cover five things, namely as follows:

Fairness

It is a principle that managers treat all stakeholders fairly and equally, both primary stakeholders (suppliers, customers, employees, investors) and secondary stakeholders (government, society, and others). This is what raises stakeholders (all stakeholder interests), not just the interests of stockholders (shareholders only).

Transparency. This means the obligation for managers to implement the principle of openness in the decision process and the delivery of information. Openness in conveying information also means that information must be complete, correct, and timely to all stakeholders. There should be no things that are kept secret, hidden, covered up, or delayed disclosure. This principle is where the managers are obliged to maintain an effective accounting system to produce reliable financial statements. For this reason, it is necessary to have clarity on the functions, implementation, and accountability of each organ so that management can run effectively. The principle is that managers are obliged to give accountability for all actions in managing the company to stakeholders as a form of trust given to them. The principle of responsibility is a logical consequence of the trust and authority given by stakeholders to company managers. This means a situation where the managers in making decisions are professional, independent, free from conflicts of interest, and free from pressure/influence from anything contrary to the prevailing laws and principles of sound management.

The Committee of Sponsoring Organizations of The Tradeway Commission (COSO) in Redding et al., (2013, p. 9) states that the operational objectives of the internal control system are related to the effectiveness and efficiency of the entity's 


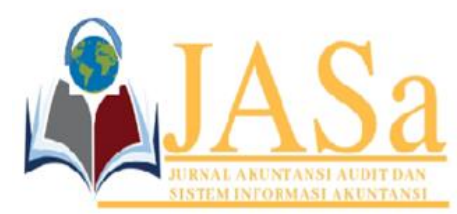

JASa (Jurnal Akuntansi, Audit dan Sistem Informasi Akuntansi)

Vol. 5 No.1/ April 2021

ISSN 2550-0732 print / ISSN 2655-8319 online

DOI;10.36555/jasa.v5i1.1507

operations, including operational and financial performance targets, and safeguarding assets from loss. Effective internal control will encourage the application of the principles of good corporate governance (Kristiana et al., 2017). The internal control system in the company encourages and assists the company to implement good corporate governance in its business activities. The internal control system in the company still needs improvement, this affects the need for more improvements to the implementation of the principles of good corporate governance as well (Widjaja dan Mustamu, 2014).

$\mathrm{H} 1$ : The internal control system affects good corporate governance.

The purpose of accounting information systems is that the existence of an information system helps the availability of information needed by all levels in the form of company management accountability reports, information systems provide information to support any decisions taken by the leadership by established responsibilities, and information systems are needed to support the smooth operation of the company. everyday (Mardi, 2014, p. 5). The accounting information system also functions to support daily company activities, support the decision-making process, assist company managers in fulfilling their responsibilities to external parties (Susanto, 2013 , p. 8). The existence of an accounting information system will support all company operational activities in an organized manner so that it has an impact on the creation of good corporate governance (Windasari, 2015).

$\mathrm{H} 2$ : The accounting information system affects good corporate governance

H3: Internal control systems and accounting information systems affects good corporate governance.

\section{METHODS}

The research methodology used in this research is verification. The study population was employees of Perum Bulog in Bandung, amounting to 4,151 employees, while the sample in this study amounted to 97 employees of Perum Bulog in Bandung. Types and sources of data used are primary data, while data collection techniques used questionnaires. The independent variable is the internal control system and accounting information system, while the dependent variable is good corporate governance. The data analysis used is multiple linear regression analysis using SPSS version 23.00.

\section{RESULTS AND DISCUSSION Results}

Tabel 1. Multiple Linear Regression

\begin{tabular}{cr}
\hline \multicolumn{1}{c}{ Variable } & Coefficient \\
\hline C & 0,250 \\
Internal Control System & 0,524 \\
Accounting Information System & 0,396
\end{tabular}

Source: SPSS Output Results 


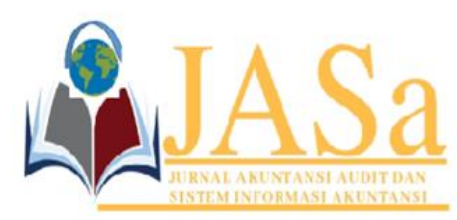

JASa (Jurnal Akuntansi, Audit dan Sistem Informasi Akuntansi)

Vol. 5 No.1/ April 2021

ISSN 2550-0732 print / ISSN 2655-8319 online

DOI;10.36555/jasa.v5i1.1507 formed is:

Based on table 1 above shows that the regression equation model that is

$$
Y=0,250+0,524 X_{1}+0,396 X_{2}
$$

Based on the regression equation above, shows that the internal control system and accounting information system have a positive influence on good corporate governance.

Tabel 2. Partial Hypothesis Testing

\begin{tabular}{cccc}
\hline Variable & $\mathbf{t}$ & Prob & Result \\
\hline ICS & $5,146>1,986$ & $0,000<0,1$ & $\mathrm{H}_{1}$ Accepted \\
AIS & $3,817>1,986$ & $0,000<0,1$ & $\mathrm{H}_{2}$ Accepted \\
\hline
\end{tabular}

Source: SPSS Output Results

Based on table 2. above partially shows that the internal control system and accounting information system affect good corporate governance.

Tabel 3. Simultaneous Hypothesis Testing

\begin{tabular}{cccc}
\hline Variable & F & Prob & Result \\
\hline ICS & \multirow{2}{*}{$158,892>3,09$} & $0,000<0,1$ & $\mathrm{H}_{3}$ Accepted \\
AIS & & & \\
\hline
\end{tabular}

Source: SPSS Output Results

Based on table 3. above, simultaneously shows that the internal control system and accounting information system affect good corporate governance.

Tabel 4. Determination Coefficient Testing

\begin{tabular}{lcc}
\hline & Value & Percentage \\
Information & & $77,2 \%$ \\
R-squared & 0,772 & \\
\hline \multicolumn{2}{l}{ Source: SPSS Output Results }
\end{tabular}

Source: SPSS Output Results

Based on table 4. above, shows that the magnitude of the influence of the internal control system and accounting information system on good corporate governance is $77.2 \%$.

\section{Discussions}

The Influence of Internal Control Systems on Good Corporate Governance

The results showed that the internal control system affected good corporate governance. The Committee of Sponsoring Organizations of The Tradeway Commission (COSO) in Redding et al., (2013, p. 9) states that the operational objectives of the internal control system are related to the effectiveness and efficiency of the entity's operations, including operational and financial performance targets, and safeguarding assets from loss. Effective internal control will encourage the application of the principles of good corporate governance (Kristiana et al., 2017). The internal 


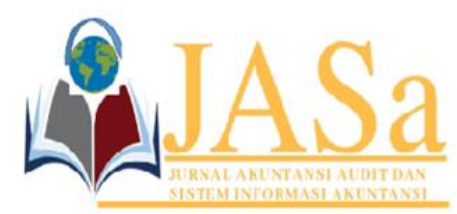

JASa (Jurnal Akuntansi, Audit dan Sistem Informasi Akuntansi)

Vol. 5 No.1/ April 2021

ISSN 2550-0732 print / ISSN 2655-8319 online

DOI;10.36555/jasa.v5i1.1507

control system in the company encourages and assists the company to implement good corporate governance in its business activities. The internal control system in the company still needs improvement, this affects the need for more improvements to the implementation of the principles of good corporate governance as well (Widjaja dan Mustamu, 2014). The results of this study are in line with the results of previous studies conducted by Wirda et al., (2012), Widjaja dan Mustamu (2014). The results of his research indicate that the internal control system affects the level of good corporate governance.

\section{The Influence of Accounting Information Systems on Good Corporate Governance}

The results showed that the accounting information system affected good corporate governance. The purpose of accounting information systems is that the existence of an information system helps the availability of information needed by all levels in the form of company management accountability reports, information systems provide information to support any decisions taken by the leadership by established responsibilities, and information systems are needed to support the smooth operation of the company. everyday (Mardi, 2014, p. 5). The accounting information system also functions to support daily company activities, support the decision-making process, assist company managers in fulfilling their responsibilities to external parties (Susanto, 2013 , p. 8). The existence of an accounting information system will support all company operational activities in an organized manner so that it has an impact on the creation of good corporate governance (Windasari, 2015). The results of this study are in line with the results of previous studies conducted by Uyar et al., (2017) dan Windasari (2015). The results of his research indicate that the accounting information system affects the level of good corporate governance.

\section{CONCLUSIONS}

Internal control systems affect good corporate governance. Accounting information systems affect good corporate governance. Internal control systems and accounting information systems affect good corporate governance.

\section{REFERENCES}

Agoes, S. (2017). Auditing: Petunjuk Praktis Pemeriksaan Akuntan oleh Akuntan Publik (Edisi 5). Salemba Empat.

Agoes, S., \& I Cenik Ardana. (2013). Etika Bisnis dan Profesi : Tantangan Membangun Manusia Seutuhnya (Edisi Revi). Salemba Empat.

Kristiana, W. L., Wahyuni, M. A., \& Sujana, E. (2017). Pengaruh Sistem Pengendalian Intern, Kinerja Organisasi, Dan Budaya Organisasi Terhadap Penerapan Good Corporate Governance. E-Journal S1 Ak Universitas Pendidikan Ganesha, Volume:7 $\mathrm{N}$.

Kurniawan, A. (2005). Transformasi Pelayanan Publik. Pembaruan.

Mardi. (2014). Sistem Informasi Akuntansi. Ghalia Indonesia. 


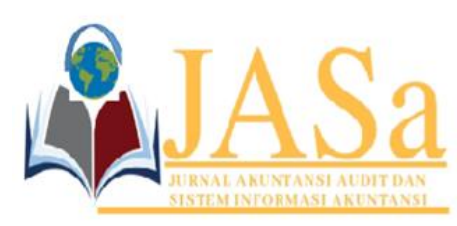

JASa (Jurnal Akuntansi, Audit dan Sistem Informasi Akuntansi)

Vol. 5 No.1/ April 2021

ISSN 2550-0732 print / ISSN 2655-8319 online

DOI;10.36555/jasa.v5i1.1507

Peraturan Menteri Badan Usaha Milik Negara. (2011). Penerapan Tata Kelola Perusahaan yang Baik (Good Corporate Governance) Pada Badan Usaha Milik Negara. Menteri Badan Usaha Milik Negara.

Redding, K. F., Sobel, P. J., \& Head., M. J. (2013). Internal Auditing: Assurance \& Advisory Services (Third Edit). The Institute of Internal Auditors Research Foundation (IIARF).

Romney, M. R., \& Steinbart, P. J. (2015). Sistem Informasi Akuntansi (S. Empat (ed.)).

Sedarmayanti. (2012). Good Governance \& Good Corporate Governance. Mandar Maju.

Susanto, A. (2013). Sistem Informasi Akuntansi. Lingga Jaya.

Uyar, A., Gungormus, A. H., \& Kuzey, C. (2017). Impact of the Accounting Information System on Corporate Governance: Evidence from Turkish Non-Listed Companies. Australasian Accounting Business and Finance Journal, Volume 11, (Issue 1 Special Issue on Corporate Governance 2017), 9-27.

Widjaja, F., \& Mustamu, R. H. (2014). Pengaruh Sistem Pengendalian Internal Terhadap Implementasi Prinsip-Prinsip Good Corporate Governance Pada Perusahaan Industri Keramik. AGORA, Vol. 2, No.

Windasari, R. (2015). Pengaruh Audit Internal Dan Sistem Informasi Akuntansi Terhadap Good Corporate Governance. UNIVERSITAS PASUNDAN.

Wirda, Darwanis, \& Jalaluddin. (2012). Pengaruh Sistem Pengendalian Intern Terhadap Penerapan Good Corporate Governance (GCG) Pada Perbankan Di Kota Banda Aceh. Jurnal Akuntansi Pascasarjana Universitas Syiah Kuala, Volume 1,(ISSN 2302-0164), 59-70. 